\title{
Agromyces allii sp. nov., isolated from the rhizosphere of Allium victorialis var. platyphyllum
}

Correspondence

Jung-Hoon Yoon

jhyoon@kribb.re.kr
The genus Agromyces, as proposed by Gledhill \& Casida (1969) and emended by Zgurskaya et al. (1992), currently includes the following species: Agromyces ramosus (Gledhill \& Casida, 1969), Agromyces cerinus (Zgurskaya et al., 1992), Agromyces mediolanus (Suzuki et al., 1996), Agromyces luteolus, Agromyces rhizospherae and Agromyces bracchium (Takeuchi \& Hatano, 2001), Agromyces albus (Dorofeeva et al., 2003), Agromyces aurantiacus (Li et al., 2003), Agromyces fucosus and Agromyces hippuratus (Zgurskaya et al., 1992; Ortiz-Martinez et al., 2004), Agromyces ulmi (Rivas et al., 2004), Agromyces neolithicus and Agromyces salentinus (Jurado et al., 2005a), Agromyces humatus, Agromyces italicus and Agromyces lapidis (Jurado et al., 2005b) and Agromyces subbeticus (Jurado et al., 2005c). Species of this genus are characterized chemotaxonomically by having MK-12 as the common predominant menaquinone, anteiso- $C_{15: 0}$, anteiso- $C_{17: 0}$ and iso- $C_{16: 0}$ as the

The GenBank/EMBL/DDBJ accession number for the 16S rRNA gene sequences of strains UMS-62 ${ }^{\top}$ and UMS-101 are D0673873 and D0673874, respectively.

A supplementary table detailing the phenotypic characteristics that differentiate species of the genus Agromyces is available in IJSEM Online. major fatty acids and by DNA $\mathrm{G}+\mathrm{C}$ contents of 65.3-73.3 mol\% (Gledhill \& Casida, 1969; Zgurskaya et al., 1992; Suzuki et al., 1996; Sasaki et al., 1998; Takeuchi \& Hatano, 2001; Dorofeeva et al., 2003; Li et al., 2003; Jurado et al., 2005a, b, c). Here, we report the detailed taxonomic characterization of two Agromyces-like bacterial strains, UMS- $62^{\mathrm{T}}$ and UMS-101, which were isolated from the rhizosphere of Allium victorialis var. platyphyllum, a type of wild edible greens grown on Ulleung island, Korea.

Strains UMS- $62^{\mathrm{T}}$ and UMS- 101 were isolated by a standard dilution plating technique at $30^{\circ} \mathrm{C}$ on nutrient agar (NA; Difco). To investigate their morphological, physiological and biochemical characteristics, the strains were routinely cultivated at $30^{\circ} \mathrm{C}$ on NA. Growth at various temperatures from 4 to $40^{\circ} \mathrm{C}$ was measured on $\mathrm{NA}$ and tolerance to various $\mathrm{NaCl}$ concentrations was measured in nutrient broth (NB; Difco). The optimal $\mathrm{pH}$ and $\mathrm{pH}$ range for growth were determined in $\mathrm{NB}$ that was adjusted to various $\mathrm{pH}$ values ( $\mathrm{pH} 4.5-10.5$ at intervals of $0.5 \mathrm{pH}$ units). Growth under anaerobic conditions was determined after incubation in an anaerobic chamber on NA and on NA supplemented with nitrate, both of which had been prepared anaerobically using nitrogen. Cell morphology and presence 
of flagella were examined by light microscopy (E600; Nikon) and transmission electron microscopy by using cells cultivated on NA. The Gram reaction was determined by using the bioMérieux Gram stain kit according to the manufacturer's instructions. Catalase and oxidase activities and hydrolysis of casein, starch, hypoxanthine, xanthine, tyrosine and Tweens 20, 40, 60 and 80 were determined as described by Cowan \& Steel (1965). Hydrolysis of aesculin, gelatin and urea and nitrate reduction were studied as described by Lanyi (1987). Acid production from carbohydrates was determined according to Leifson (1963). Utilization of various substrates for growth was investigated as described by Yurkov et al. (1994). The API ZYM system (bioMérieux) was used to characterize enzyme activity. The API 20E system (bioMérieux) was used to examine other physiological and biochemical properties. Susceptibility to antibiotics was tested on NA plates using antibiotic discs containing the following concentrations of antibiotic; ampicillin $(10 \mu \mathrm{g})$, carbenicillin $(100 \mu \mathrm{g})$, cephalothin $(30 \mu \mathrm{g})$, chloramphenicol $(100 \mu \mathrm{g})$, gentamicin $(30 \mu \mathrm{g})$, lincomycin $(15 \mu \mathrm{g})$, kanamycin $(30 \mu \mathrm{g})$, neomycin $(30 \mu \mathrm{g})$, novobiocin $(5 \mu \mathrm{g})$, oleandomycin $(15 \mu \mathrm{g})$, penicillin $\mathrm{G}$ $(20 \mathrm{U})$, polymyxin B (100 IU), streptomycin $(50 \mu \mathrm{g})$ and tetracycline $(30 \mu \mathrm{g})$.

Strains UMS- $62^{\mathrm{T}}$ and UMS- 101 were cultivated for 3 days in $\mathrm{NB}$ at $30^{\circ} \mathrm{C}$ to obtain the cell biomass required for DNA extraction and analyses of isoprenoid quinones, polar lipids and whole-cell sugars. Chromosomal DNA was extracted and purified according to a previously described procedure (Yoon et al., 1996). 16S rRNA gene amplification was conducted according to the method described previously using two universal primers (Yoon et al., 1998). Sequencing of the amplified $16 \mathrm{~S}$ rRNA gene was performed as described by Yoon et al. (2003). A phylogenetic analysis was conducted using the CLUSTAL W software package (Thompson et al., 1994). Isoprenoid quinones were analysed as described previously (Komagata \& Suzuki, 1987) using reverse-phase HPLC. For fatty acid methyl ester analysis, cell mass of strains UMS- $62^{\mathrm{T}}$ and UMS-101 was harvested from NA plates after cultivation for 3 days at $30^{\circ} \mathrm{C}$. Fatty acid methyl esters were extracted and prepared according to the standard protocol of the MIDI/Hewlett Packard Microbial Identification System (Sasser, 1990). Polar lipids were extracted according to Minnikin et al. (1984) and were identified using two dimensional TLC followed by spraying with appropriate detection reagents (Minnikin et al., 1984; Komagata \& Suzuki, 1987). Whole-cell sugars were analysed as described previously (Staneck \& Roberts, 1974). The DNA G + C content was determined by the method of Tamaoka \& Komagata (1984). DNA-DNA relatedness was determined by the microplate hybridization method (Ezaki et al., 1989) using photobiotin-labelled DNA probes. The type strains of five Agromyces species were used as reference strains for DNA-DNA hybridization. Samples of $A$. salentinus DSM $16198^{\mathrm{T}}$, A. lapidis DSM $16390^{\mathrm{T}}$, A. italicus DSM $16388^{\mathrm{T}}$, A. ramosus DSM $43045^{\mathrm{T}}$ and A. neolithicus DSM $16197^{\mathrm{T}}$ were obtained from the Deutsche Sammlung von Mikroorganismen und Zellkulturen (DSMZ), Braunschweig, Germany.

Morphological, cultural, physiological and biochemical characteristics of strains UMS- $62^{\mathrm{T}}$ and UMS-101 are given in the species description (see below) or are shown in Table 1 and Supplementary Table S1 in IJSEM Online. The almost complete 16S rRNA gene sequences of strains UMS- $62^{\mathrm{T}}$ and UMS-101 determined in this study each comprised $1483 \mathrm{nt}$. The $16 \mathrm{~S}$ rRNA gene sequences of the two novel strains were $99.9 \%$ similar, showing only two nucleotide differences. Comparative $16 \mathrm{~S}$ rRNA gene sequence analyses showed that strains UMS- $62^{\mathrm{T}}$ and UMS-101 fell within the radiation of the cluster comprising the recognized Agromyces species (Fig. 1).

The chemotaxonomic properties of the two novel strains were in agreement with their phylogenetic affiliation to the genus Agromyces. Strains UMS-62 ${ }^{\mathrm{T}}$ and UMS-101 contained MK-11 and MK-12 as the predominant menaquinones at peak area ratios of approximately $45-47 \%$ and $35-38 \%$, respectively. The cellular fatty acid profiles of strains UMS-62 ${ }^{\mathrm{T}}$ and UMS-101 are shown in Table 2, together with those of some phylogenetically related Agromyces species. Strains UMS- $62^{\mathrm{T}}$ and UMS-101 contained large amounts of straight-chain and branched fatty acids; the major components $\left(>10 \%\right.$ of total fatty acids) were anteiso- $\mathrm{C}_{15: 0}$ $(34.3-39.1 \%)$, iso- $\mathrm{C}_{16: 0}(11.8-28.7 \%)$ and anteiso- $\mathrm{C}_{17: 0}$ (17.0-18.3\%). $\mathrm{C}_{16: 0}(6.4-24.1 \%)$ was detected as a major component only in strain UMS-101. The fatty acid profiles of the two novel strains were similar to those of recognized Agromyces species, although there were differences in the proportions of some fatty acids, perhaps because of differences in cultivation conditions and extraction procedures (Takeuchi \& Hatano, 2001; Li et al., 2003; Jurado et al., 2005a, b, c). The major polar lipids detected in strains UMS- $62^{\mathrm{T}}$ and UMS-101 were diphosphatidylglycerol, phosphatidylglycerol and an unidentified glycolipid. The wholecell sugars detected in the novel strains were rhamnose, ribose and galactose; xylose was detected only in strain UMS- $62^{\mathrm{T}}$. Minor amounts of mannose and glucose were also detected. The DNA G + C contents of strains UMS- $62^{\mathrm{T}}$ and UMS-101 were 71.1 and $71.3 \mathrm{~mol} \%$, respectively.

Strains UMS-62 ${ }^{\mathrm{T}}$ and UMS-101 exhibited 16S rRNA gene sequence similarity values of $97.0-99.1 \%$ with respect to the type strains of A. salentinus, A. lapidis, A. italicus, A. ramosus and A. neolithicus and of 95.2-96.9\% with the type strains of the other recognized Agromyces species (Fig. 1). Strains UMS$62^{\mathrm{T}}$ and UMS-101 exhibited a mean DNA-DNA relatedness value of $91.1 \%$ when their DNAs were used individually as labelled DNA probes for cross-hybridization. This value indicates that strains UMS- $62^{\mathrm{T}}$ and UMS- 101 are members of the same genomic species (Wayne et al., 1987). Levels of DNA-DNA relatedness between strains UMS-62 ${ }^{\mathrm{T}}$ and UMS101 and the type strains of A. salentinus, A. lapidis, A. italicus, A. ramosus and A. neolithicus, which showed 16S rRNA gene sequence similarity values of $>97.0 \%$ to the two novel strains, were in the range $13.4-54.2 \%$, indicating that the two 
Table 1. Differential phenotypic characteristics of Agromyces allii sp. nov. and some phylogenetically related Agromyces species

Species: 1, A. allii sp. nov.; 2, A. neolithicus (data from Jurado et al., 2005a); 3, A. salentinus (Jurado et al., 2005a); 4, A. italicus (Jurado et al., 2005b); 5, A. lapidis (Jurado et al., 2005b). All species are positive for catalase activity, hydrolysis of casein, acid production from cellobiose, galactose, D-glucose, maltose and mannose and are susceptible to ampicillin, novobiocin (not determined for A. neolithicus and A. salentinus) and penicillin G. All species are negative for hydrolysis of Tween 80 , indole production and utilization of benzoate (not determined for A. italicus and A. lapidis) and citrate. +, Positive; -, negative; v, variable; W, weakly positive; ND, not determined. Data in parentheses refer to the type strain.

\begin{tabular}{|c|c|c|c|c|c|}
\hline Characteristic & 1 & 2 & 3 & 4 & 5 \\
\hline Temperature range for growth $\left({ }^{\circ} \mathrm{C}\right)$ & $4-33$ & $15-37$ & $10-37$ & $10-37$ & $10-37$ \\
\hline \multicolumn{6}{|l|}{ Growth in/at: } \\
\hline $37^{\circ} \mathrm{C}$ & - & + & + & + & + \\
\hline $10^{\circ} \mathrm{C}$ & + & - & + & $\mathrm{w}$ & $\mathrm{w}$ \\
\hline $\mathrm{NaCl} 4.0 \%(\mathrm{w} / \mathrm{v})$ & - & - & + & + & + \\
\hline Nitrate reduction & + & + & - & + & + \\
\hline Oxidase activity & + & $\mathrm{V}$ & $\mathrm{V}$ & + & $\mathrm{V}$ \\
\hline \multicolumn{6}{|l|}{ Hydrolysis of: } \\
\hline Gelatin & + & + & - & + & $\mathrm{V}$ \\
\hline Hypoxanthine & - & - & - & + & - \\
\hline Tyrosine & - & + & + & + & + \\
\hline Urea & - & - & + & - & - \\
\hline Xanthine & - & - & - & + & - \\
\hline $\mathrm{H}_{2} \mathrm{~S}$ production & - & + & + & + & + \\
\hline \multicolumn{6}{|l|}{ Acid production from: } \\
\hline L-Arabinose & + & + & + & + & - \\
\hline Lactose & + & - & - & $\mathrm{W}$ & - \\
\hline Mannitol & - & + & - & - & - \\
\hline D-Raffinose & - & + & $\mathrm{W}$ & - & $\mathrm{W}$ \\
\hline Rhamnose & + & - & + & - & - \\
\hline Ribose & + & - & + & - & - \\
\hline Salicin & + & - & + & + & + \\
\hline Sucrose & + & $\mathrm{V}$ & + & - & + \\
\hline Trehalose & + & - & + & - & - \\
\hline D-Xylose & + & - & + & + & - \\
\hline \multicolumn{6}{|l|}{ Utilization of: } \\
\hline Acetate & $\mathrm{V}(-)$ & - & + & ND & ND \\
\hline Malate & + & - & - & - & - \\
\hline Succinate & + & - & - & - & - \\
\hline \multicolumn{6}{|l|}{ Enzyme activity (API ZYM): } \\
\hline$\alpha$-Chymotrypsin & $\mathrm{v}(+)$ & + & - & - & + \\
\hline$\alpha$-Galactosidase & - & + & - & - & - \\
\hline$\beta$-Galactosidase & + & - & + & + & + \\
\hline$\beta$-Glucuronidase & + & + & - & - & - \\
\hline \multicolumn{6}{|l|}{ Antibiotic susceptibility: } \\
\hline Kanamycin & + & - & + & - & - \\
\hline Polymyxin B & + & + & + & - & - \\
\hline DNA G $+\mathrm{C}$ content $(\mathrm{mol} \%)$ & $71.1-71.3$ & 65.3 & 72.3 & 70.8 & 70.4 \\
\hline
\end{tabular}

novel strains represent a different genomic species to the five recognized Agromyces species tested (Wayne et al., 1987). Strains UMS- $62^{\mathrm{T}}$ and UMS-101 also differed from the recognized Agromyces species in several phenotypic characteristics (Table 1; Supplementary Table S1 in IJSEM Online). Phylogenetic distinctiveness, DNA-DNA relatedness data and differential phenotypic properties suggest that strains UMS- $62^{\mathrm{T}}$ and UMS-101 represent a species that is distinct from the recognized Agromyces species. Therefore, on the basis of the data presented, strains UMS- $62^{\mathrm{T}}$ and UMS101 should be placed in the genus Agromyces as a novel species, for which the name Agromyces allii sp. nov. is proposed. 


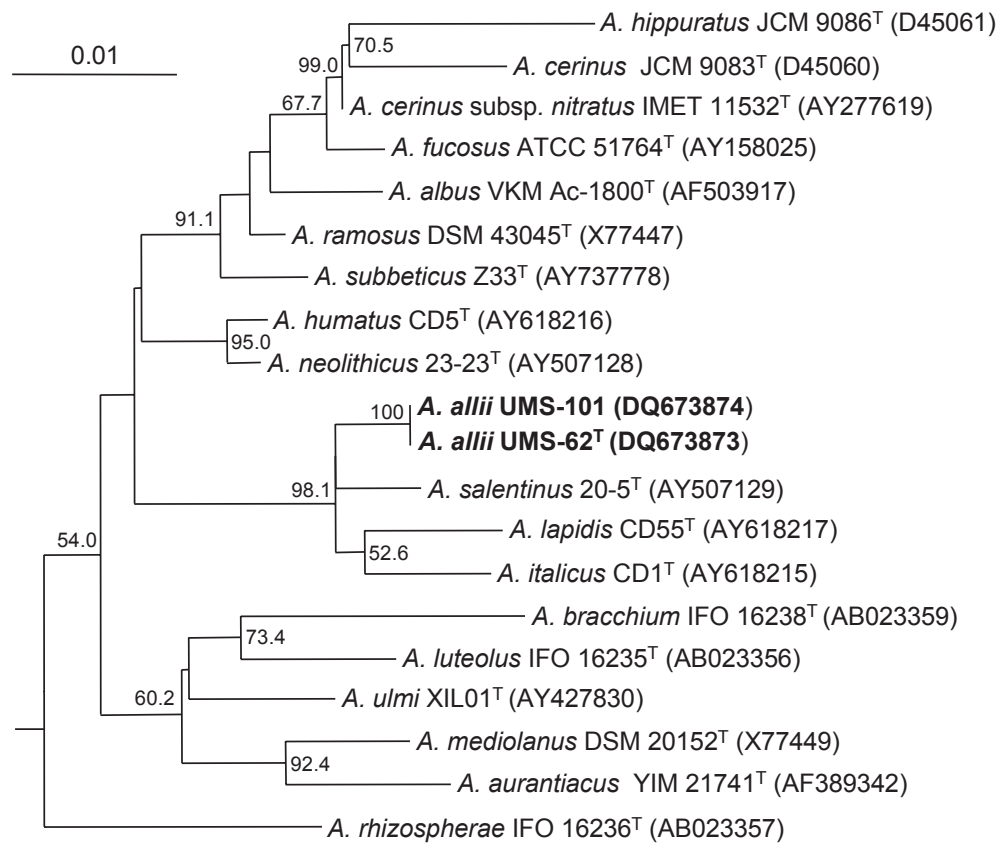

Fig. 1. Neighbour-joining tree showing the phylogenetic positions of strains UMS $-62^{\top}$, UMS-101 and other recognized Agromyces species based on 16S rRNA gene sequences. Only bootstrap values (expressed as percentages of 1000 replications) of greater than $50 \%$ are shown at the branching points. Arthrobacter globiformis DSM $20124^{\top}$ (M23411) was used as an outgroup (not shown). Bar, 0.01 substitutions per nucleotide position.

\section{Description of Agromyces allii sp. nov.}

Agromyces allii (al.li'i. N.L. gen. n. allii of Allium, referring to the source of isolation of the micro-organisms, the rhizosphere of Allium victorialis var. platyphyllum).

Cells are Gram-positive, slightly curved, rod-shaped and $0.2-0.4 \times 0.5-1.5 \mu \mathrm{m}$. Non-motile. Strictly aerobic. Colonies are circular, convex, smooth and yellow. Growth occurs at 4 and $33^{\circ} \mathrm{C}$, with an optimum temperature of $30^{\circ} \mathrm{C}$. Optimal pH for growth is between 6.5 and 7.5; growth occurs at $\mathrm{pH}$ 5.5, but not at 5.0. Growth occurs at $<3 \%$ $(\mathrm{w} / \mathrm{v}) \mathrm{NaCl}$. Aesculin is hydrolysed, but starch and Tweens 20, 40 and 60 are not. Arginine decarboxylase, lysine decarboxylase, ornithine decarboxylase and tryptophan deaminase are absent. D-Glucose, D-galactose, D-cellobiose, D-mannose, D-trehalose, D-xylose, L-arabinose, sucrose,

Table 2. Cellular fatty acid content (\%) of strains UMS $-62^{\top}$, UMS-101 and some other recognized species of the genus Agromyces

Strains: 1, A. allii sp. nov. strain UMS-62 ${ }^{\mathrm{T}}$ (results for strain UMS-101 are given in parentheses); 2, A. bracchium IFO $16238^{\mathrm{T}}$ (data from Takeuchi \& Hatano, 2001); 3, A. luteolus IFO $16235^{\mathrm{T}}$ (Takeuchi \& Hatano, 2001); 4, A. rhizospherae IFO 16236 ${ }^{\mathrm{T}}$ (Takeuchi \& Hatano, 2001); 5, A. aurantiacus YIM $21741^{\mathrm{T}}$ (Li et al., 2003); 6, A. ulmi XIL01 ${ }^{\mathrm{T}}$ (Rivas et al., 2004); 7, A. neolithicus 23-23 ${ }^{\mathrm{T}}$ (Jurado et al., 2005a); 8, A. salentinus 20-5 (Jurado et al., 2005a); 9, A. humatus $\mathrm{CD}^{\mathrm{T}}$ (Jurado et al., 2005b); 10, A. italicus $\mathrm{CD}^{\mathrm{T}}{ }^{\mathrm{T}}$ (Jurado et al., 2005b); 11, A. lapidis $\mathrm{CD}_{5} 5^{\mathrm{T}}$ (Jurado et al., 2005b); 12, A. subbeticus $\mathrm{Z}^{3}{ }^{\mathrm{T}}$ (Jurado et al., 2005c). Values are percentage of total fatty acids. -, Not detected or not described.

\begin{tabular}{|lcccccccccccc|}
\hline Fatty acid & $\mathbf{1}$ & $\mathbf{2}$ & $\mathbf{3}$ & $\mathbf{4}$ & $\mathbf{5}$ & $\mathbf{6}$ & $\mathbf{7}$ & $\mathbf{8}$ & $\mathbf{9}$ & $\mathbf{1 0}$ & $\mathbf{1 1}$ & $\mathbf{1 2}$ \\
\hline Saturated fatty acids: & & & & & & & & & & & & \\
$\mathrm{C}_{14: 0}$ & $0.4(1.6)$ & - & - & - & 0.3 & - & - & - & - & - & - & - \\
$\mathrm{C}_{15: 0}$ & $1.5(0.8)$ & - & - & - & - & - & - & - & - & - & - & - \\
$\mathrm{C}_{16: 0}$ & $6.4(24.1)$ & - & - & - & 4.2 & - & - & - & 1.3 & 1.7 & 5.9 & 1.0 \\
$\mathrm{C}_{17: 0}$ & $0.7(0.8)$ & - & - & - & - & - & - & - & - & - & - & - \\
$\mathrm{C}_{18: 0}$ & $-(1.5)$ & - & - & - & - & - & - & - & - & - & - & - \\
Branched fatty acids: & & & & & & & & & & & & - \\
iso-C $14: 0$ & $2.0(1.0)$ & - & 4.1 & - & - & - & - & - & - & - & - & - \\
iso-C $15: 0$ & $3.2(3.8)$ & 4.3 & 6.1 & 7.7 & 8.5 & - & 12.8 & 6.0 & 5.4 & 14.2 & 10.5 & 16.3 \\
anteiso-C & $39.1(34.3)$ & 41.6 & 32.5 & 26.1 & 37.3 & 46.2 & 37.8 & 52.0 & 41.5 & 50.9 & 48.1 & 45.6 \\
iso-C & $28.7(11.8)$ & 28.1 & 47.9 & 53.3 & 20.1 & 25.3 & 13.0 & 12.9 & 15.5 & 14.7 & 16.5 & 12.4 \\
iso-C & $1.1(2.0)$ & - & - & - & 2.0 & - & 3.4 & 2.2 & - & - & - & 3.6 \\
anteiso- & $17.0(18.3)$ & 26.0 & 9.4 & 12.9 & 23.6 & 19.6 & 31.9 & 24.8 & 34.0 & 15.3 & 13.0 & 20.4 \\
\hline
\end{tabular}


maltose and salicin are utilized as sole carbon and energy sources, but D-fructose, pyruvate, formate and L-glutamate are not. Acid is produced from melibiose, but not from Dsorbitol, myo-inositol and D-melezitose. Acid production from D-fructose is variable (positive for type strain). Using the API ZYM system, esterase(C4), esterase lipase (C8), leucine arylamidase, valine arylamidase, cystine arylamidase, acid phosphatase, naphthol-AS-BI phosphohydrolase, $\alpha$-glucosidase, $\beta$-glucosidase and $N$-acetyl- $\beta$-glucosaminidase activities are present, but alkaline phosphatase, lipase (C14), trypsin, $\alpha$-mannosidase and $\alpha$-fucosidase activities are absent. Susceptible to streptomycin, chloramphenicol, cephalothin, gentamicin, tetracycline, lincomycin, oleandomycin, neomycin and carbenicillin. The predominant menaquinones are MK-11 and MK-12. The major cellular fatty acids are anteiso- $\mathrm{C}_{15: 0}$, iso- $\mathrm{C}_{16: 0}$ and anteiso- $\mathrm{C}_{17: 0}$. Major polar lipids are diphosphatidylglycerol, phosphatidylglycerol and an unidentified glycolipid. Cell-wall sugars are rhamnose, ribose and galactose; xylose is detected only in the type strain as the major component. The DNA G+C content is $71.1-71.3 \mathrm{~mol} \%$.

The type strain, strain UMS- $62^{\mathrm{T}}\left(=\mathrm{KCTC} 19181^{\mathrm{T}}=\mathrm{JCM}\right.$ $13584^{\mathrm{T}}$ ), was isolated from the rhizosphere of Allium victorialis var. platyphyllum, a type of wild edible greens grown on Ulleung island, Korea.

\section{Acknowledgements}

This work was supported by the 21C Frontier Program of Microbial Genomics and Applications (grant MG05-0401-2-0) from the Ministry of Science and Technology (MOST) of the Republic of Korea.

\section{References}

Cowan, S. T. \& Steel, K. J. (1965). Manual for the Identification of Medical Bacteria. London: Cambridge University Press.

Dorofeeva, L. V., Krausova, V. I., Evtushenko, L. I. \& Tiedje, J. M. (2003). Agromyces albus sp. nov., isolated from a plant (Androsace sp.). Int J Syst Evol Microbiol 53, 1435-1438.

Ezaki, T., Hashimoto, Y. \& Yabuuchi, E. (1989). Fluorometric deoxyribonucleic acid-deoxyribonucleic acid hybridization in microdilution wells as an alternative to membrane filter hybridization in which radioisotopes are used to determine genetic relatedness among bacterial strains. Int J Syst Bacteriol 39, 224-229.

Gledhill, W. E. \& Casida, L. E., Jr (1969). Predominant catalasenegative soil bacteria. III. Agromyces, gen. n., microorganisms intermediary to Actinomyces and Nocardia. Appl Microbiol 18, 340-349.

Groth, I., Schumann, P., Weiss, N., Martin, K. \& Rainey, F. A. (1996). Agrococcus jenensis gen. nov., sp. nov., a new genus of actinomycetes with diaminobutyric acid in the cell wall. Int J Syst Bacteriol 46, 234-239.

Jurado, V., Groth, I., Gonzalez, J. M., Laiz, L. \& Saiz-Jimenez, C. (2005a). Agromyces salentinus sp. nov. and Agromyces neolithicus sp. nov. Int J Syst Evol Microbiol 55, 153-157.

Jurado, V., Groth, I., Gonzalez, J. M., Laiz, L., Schuetze, B. \& SaizJimenez, C. (2005b). Agromyces italicus sp. nov., Agromyces humatus sp. nov. and Agromyces lapidis sp. nov., isolated from Roman catacombs. Int J Syst Evol Microbiol 55, 871-875.
Jurado, V., Groth, I., Gonzalez, J. M., Laiz, L. \& Saiz-Jimenez, C. (2005c). Agromyces subbeticus sp. nov., isolated from a cave in southern Spain. Int J Syst Evol Microbiol 55, 1897-1901.

Komagata, K. \& Suzuki, K. (1987). Lipids and cell wall analysis in bacterial systematics. Methods Microbiol 19, 161-207.

Lanyi, B. (1987). Classical and rapid identification methods for medically important bacteria. Methods Microbiol 19, 1-67.

Leifson, E. (1963). Determination of carbohydrate metabolism of marine bacteria. J Bacteriol 85, 1183-1184.

Li, W.-J., Zhang, L.-P., Xu, P., Cui, X.-L., Xu, L.-H., Zhang, Z., Schumann, P., Stackebrandt, E. \& Jiang, C.-L. (2003). Agromyces aurantiacus sp. nov., isolated from a Chinese primeval forest. Int J Syst Evol Microbiol 53, 303-307.

Minnikin, D. E., O’Donnell, A. G., Goodfellow, M., Alderson, G., Athalye, M., Schaal, A. \& Parlett, J. H. (1984). An integrated procedure for the extraction of bacterial isoprenoid quinones and polar lipids. J Microbiol Methods 2, 233-241.

Ortiz-Martinez, A., Gonzalez, J. M., Evtushenko, L. I., Jurado, V., Laiz, L., Groth, I. \& Saiz-Jimenez, C. (2004). Reclassification of Agromyces fucosus subsp. hippuratus as Agromyces hippuratus sp. nov., comb. nov. and emended description of Agromyces fucosus. Int J Syst Evol Microbiol 54, 1553-1556.

Rivas, R., Trujillo, M. E., Mateos, P. F., Martínez-Molina, E. \& Velázquez, E. (2004). Agromyces ulmi sp. nov., a xylanolytic bacterium isolated from Ulmus nigra in Spain. Int J Syst Evol Microbiol 54, 1987-1990.

Sasaki, J., Chijimatsu, M. \& Suzuki, K. (1998). Taxonomic significance of 2,4-diaminobutyric acid isomers in the cell wall peptidoglycan of actinomycetes and reclassification of Clavibacter toxicus as Rathayibacter toxicus comb. nov. Int J Syst Bacteriol 48, 403-410.

Sasser, M. (1990). Identification of Bacteria by Gas Chromatography of Cellular Fatty Acids, Midi Technical Note 101. Newark, DE: MIDI Inc.

Staneck, J. L. \& Roberts, G. D. (1974). Simplified approach to identification of aerobic actinomycetes by thin-layer chromatography. Appl Microbiol 28, 226-231.

Suzuki, K., Sasaki, J., Uramoto, M., Nakase, T. \& Komagata, K. (1996). Agromyces mediolanus sp. nov., nom. rev., comb. nov., a species for "Corynebacterium mediolanum" Mamoli 1939 and for some aniline-assimilating bacteria which contain 2,4-diaminobutyric acid in the cell wall peptidoglycan. Int J Syst Bacteriol 46, 88-93.

Takeuchi, M. \& Hatano, K. (2001). Agromyces luteolus sp. nov., Agromyces rhizospherae sp. nov. and Agromyces bracchium sp. nov., from the mangrove rhizosphere. Int J Syst Evol Microbiol 51, 1529-1537.

Tamaoka, J. \& Komagata, K. (1984). Determination of DNA base composition by reversed-phase high-performance liquid chromatography. FEMS Microbiol Lett 25, 125-128.

Thompson, J. D., Higgins, D. G. \& Gibson, T. J. (1994). CLUSTAL W: improving the sensitivity of progressive multiple sequence alignment through sequence weighting, position-specific gap penalties and weight matrix choice. Nucleic Acids Res 22, 4673-4680.

Wayne, L. G., Brenner, D. J., Colwell, R. R., Grimont, P. A. D., Kandler, O., Krichevsky, M. I., Moore, L. H., Moore, W. E. C., Murray, R. G. E. \& other authors (1987). International Committee on Systematic Bacteriology. Report of the ad hoc committee on reconciliation of approaches to bacterial systematics. Int $J$ Syst Bacteriol 37, 463-464.

Yoon, J.-H., Kim, H., Kim, S.-B., Kim, H.-J., Kim, W. Y., Lee, S. T., Goodfellow, M. \& Park, Y.-H. (1996). Identification of Saccharomonospora strains by the use of genomic DNA fragments and rRNA gene probes. Int J Syst Bacteriol 46, 502-505. 
Yoon, J.-H., Lee, S. T. \& Park, Y.-H. (1998). Inter- and intraspecific phylogenetic analysis of the genus Nocardioides and related taxa based on 16S rDNA sequences. Int J Syst Bacteriol 48, 187-194.

Yoon, J.-H., Kim, I.-G., Kang, K. H., Oh, T.-K. \& Park, Y.-H. (2003). Alteromonas marina sp. nov., isolated from sea water of the East Sea in Korea. Int J Syst Evol Microbiol 53, 1625-1630.

Yurkov, V., Stackebrandt, E., Holmes, A., Fuerst, J. A., Hugenholtz, P., Golecki, J., Gad'on, N., Gorlenko, V. M., Kompantseva, E. I. \& Drews, G. (1994). Phylogenetic positions of novel aerobic, bacteriochlorophyll a-containing bacteria and description of Roseococcus thiosulfatophilus gen. nov., sp. nov., Erythromicrobium ramosum gen. nov., sp. nov., and Erythrobacter litoralis sp. nov. Int J Syst Bacteriol 44, 427-434.

Zgurskaya, H. I., Evtushenko, L. I., Akimov, V. N., Voyevoda, H. V., Dobrovolskaya, T. G., Lysak, L. V. \& Kalakoutskii, L. V. (1992). Emended description of the genus Agromyces and description of Agromyces cerinus subsp. cerinus sp. nov., subsp. nov., Agromyces cerinus subsp. nitratus sp. nov., subsp. nov., Agromyces fucosus subsp. fucosus sp. nov., subsp. nov., and Agromyces fucosus subsp. hippuratus sp. nov., subsp. nov. Int J Syst Bacteriol 42, 635-641. 